\title{
About Rhetorical "Gestures" of Estonian Culture
}

\author{
REIN VEIDEMANN
}

\begin{abstract}
The paper focuses on the analysis of certain phrases of literary origin currently used in Estonian culture. The theoretical-methodological starting point is the paradigm of cultural semiotics. According to the theory the production, exchange, processing and retention of signs (resp information) is by its nature communication. In such communication socio-cultural (having an impact on social relations) and rhetorical (having an impact on the social and cultural discourse) aspects are distinguished. The phrases of literary or other origin (e.g. political texts) used in the language generally differ from the phraseologisms originating from the folklore and idioms in that they are not used for beautifying the language so to say (as a figure of speech) but to refer to the fundamental (meta-communicative) associations and act as passwords of collective identity. Therefore, they can be identified as rhetorical gestures. The article takes a closer look at phrases, which have become rhetorical gestures taken from the masterpieces of Estonian literary culture such as Henrik's Livonian Chronicles, Fr. R. Kreutzwald's epic Kalevipoeg (Kalev's Son), poetry by Juhan Liiv, Kevade (Spring) by Oskar Luts, and Tõde ja õigus (Truth and Justice) by A. H. Tammsaare.
\end{abstract}

Keywords: internal communication of culture, idiomatics, Estonian literature as a source of cultural passwords

\section{Introduction}

Cultural semiotics, which forms the main methodological basis of this paper, discusses the term culture in the paradigm of communication. It is expressively reflected already in the title of the internationally acknowledged work Universe of the Mind by Yuri Lotman (1922-1993) (Lotman 1990), who was one of the founders of the Tartu-Moscow school of cultural semiotics. The production of signs, their exchange, processing and retention to which the most important functions and mechanisms of culture are related (Lotman, M. 2001: 218), constitutes communication by nature. Beside the exchange of signs, rhetorical (having an impact on the discourse) (Craig 1999: 135-136) and socio-cultural 
(having an impact in social aspects and the shaping of the collective identity (ib. 144-146) is kept in mind.

Furthermore, both aspects may be observed as the internal communication of culture. The socio-cultural internal communication of culture denotes that a reference to objects in geographical space within collective interaction, to the narratives surrounding them, historical events and figures, to the works of literature, art and music rises above the primary meaning of these objects. They become symbolic signs. Such objects (resp artefacts) in Estonian culture, which have acquired the status of symbolic signs, have been discussed by the author in his earlier publications of Interlitteraria (Veidemann 2011: 418-440). In this paper the author is going to observe the rhetorical aspect of internal communication. It differs from the socio-cultural aspect not only due to the fact that it claims that acts have some symbolic value or conditions in one or another culture, but rather because the rhetorical intensification of the intracultural dialogue between participants produces a joint discourse.

We have to agree that a human being is homo rhetoricus (Osterreich 2002: 289-290), which among other things means that verbal communication comprises similies and figures of speech. The latter include a substantial variety of phraseologisms and idioms. Many of them are of literary origin and have their own life in (cultural) history. It means that they have broken free from the context of the work and refer to a much wider and sometimes even to a fundamental circle of associations. It is one thing is to talk about the question "To be or not to be?" in Shakespeare's Hamlet but it is another thing when this question circulates in the cultural discourse. Then, according to the author's opinion, it is already a rhetorical gesture - the use of a literary quotation with the purpose of interpreting or providing a metaphoric intensification of a wider complex of meanings. In linguistic interaction it may be handled as the reception and transmission of metaphors (Corradi Fiumara 1995: 139-142). By the way, Hamlet's question is a genuine phenomenon of intra-cultural communication, or in other words, by using the phrase, the dialogue partners coming from different nations signal being on the same discourse field. Next the author observes some rhetorical gestures circulating in the Estonian cultural discourse (including literature) and their origin and functioning aspects. The author admits that this analysis is not based on a statistic and systematic study of a major text corpus, but on the experience of a person who has followed Estonian media, including radio and television and has been reading a big variety of literary texts for decades. 
VEIDEMANN

\section{"Laula! Laula! Pappi"1}

This phrase is one of the oldest written texts in the Estonian language. It comes from a story describing the christening of Estonians recorded by Livonian Henrik and is included in the Livonian Chronicle of 1227 (Henriku Liivimaa kroonika 1982: 154-155). A copy of the manuscript written in Latin was found in 1862 and published in German in 1867. Carl Robert Jakobson (1841-1882), one of the leaders of the Estonian national movement, quotes and interprets the phrase in his first patriotic speech in 1870. From then on the chronicle appears to be not only a part of the Estonian literature but the entire historical and cultural discourse. Henrik quotes Estonians (specifically islanders) in an episode, in which the latter torture one Cistercian priest. Before his execution, the priest Frederic prays to the heavens, which, according to the chronicler, was jeered at by Estonians who shouted "Sing! Sing! Priest". Even if the chronicler's remark was not true, Estonians regarded it as having really happened and the phrase is fixed the Estonian language. In the Estonian language the phrase is fixed as a sentence expressing irony towards empty words and hypocritical performance. The explanatory dictionary of the Estonian language (Eesti keele seletav sonaraamat) explains the sentence as follows: "You will sing another song and say something else when you see the real situation ("Küll siis laulad teist laulu 'räägid teist juttu', kui tegelikku olukorda näed.") (EKSS 2009: 72). It may be assumed that the roots of this phraseologism can be dated back a thousand years, when Henrik wrote it down.

According to the theory of speaking acts, the utterance "Sing! Sing! Priest!" may be classified as belonging to imperative statements (rhetorical questions and exclamations). It implicitly reflects the unconcealed insincerity, which characterises ironic acts of speech (Haverkate 1990: 101, Ennus 2002: 12): you may pray as much as you want but it will not help you.

\section{"Aga ükskord algab aega"2}

This introductory phrase of a promise originates from one of the texts recognised as a core text of Estonian culture (Laak 2013: 192-209) Fr. R. Kreutzwald's (1803-1882) epic Kalevipoeg (Kalev's son) (1857-1861). Many motifs of the epic, storylines and characters (primarily the mythological Kalevipoeg himself, Saarepiiga, and the Finnish smith, etc.) have been

\footnotetext{
'Sing! Sing! Priest!'

2 'But once the time will come'
} 
quoted, reproduced (parodies and pastiches) and developed in other Estonian literary works and pieces of art. Marin Laak, who has been following the literary reception of Kalevipoeg, states that poetry on the theme of Kalevipoeg and also other texts have been created in a variety of ways due to which "their connection with the base text may be observed only if one knows the text of the epic very well and from close reading" (Laak 2013: 202).

It has to be pointed out that we are dealing with a promise from the epilogue of the epic, in which the focal motifs are international (Oinas 1994: 54): Kalevipoeg may be compared to Prometheus chained to a rock; every attempt to break free from then chains causes earthquakes. But the sentence "Aga ükskord algab aega" stresses the existentialistic hope for a major cataclysm thanks to which Kalevipoeg will be freed from his chains and he can return to bring happiness to his people. The image of return and happiness in this "powerful symbol" (Laak 2013: 203) is actualised during major turning points in Estonian history, during the time of major "cultural explosions" like the culmination of the national movement during the years 1870-1880 and a century later, and in the 1980s during the singing revolution (Laak 2013: 203). Kalevipoeg as a symbol of freedom was already being read when the Estonian Student Society was founded in 1870, and literary evenings devoted to Kalevipoeg (public readings of the epic) were organised (Jansen 2004: 279). The metaphor denoting freedom "Aga ükskord algab aega" sounded during the culmination of the Singing Revolution on the Song Festival Grounds in Tallinn on September 11, 1988, at the demonstration "Eestimaa laul" ("Song of Estonia”), in which approximately two hundred thousand people took part, where one of the speakers - Heinz Valk ended his speech with a challenging exclamation "Ükskord me võidame niikuinii!" ("One day, no matter what, we shall win!”). The combination of hope from Kalevipoeg (Valk 2014) and Heinz Valk's imperative became an inspirational slogan which culminated with the re-establishment of independence in Estonia on August 20, 1991.

\section{"Ta lendab mesipuu poole"3}

The phrase by one of the greatest Estonian poets Juhan Liiv (1864-1913) repeated in the title and varied in the poem, published in the magazine Linda in 1905 , is one of the many rhetorical gestures based on J. Liiv's work circulating in the collective consciousness of Estonians.

\footnotetext{
3 'It Flies to the Hive' - translated by Jüri Talvet \& H. L. Hix (Liiv 2007: 93).
} 
VEIDEMANN

Allusions to Liiv's poetry can be found in the poetry by Kalju Lepik (1920-1999), Paul-Eerik Rummo (born 1942) and Viivi Luik (born 1946), to mention only some authors representing Estonian classical poetry. Thanks to Jüri Talvet - the most outstanding Estonian expert of Liiv's poetry - and translator H. L. Hix the poem is available also in the English language and reads as follows:
It Flies to the Hive
It flies from flower to flower,
it flies to the hive;
when a thundercloud threatens,
it flies to the hive.
Thousands will fall on the way -
Still thousands will reach home.
They will carry suffering and care
and fly to the hive.
Thus soul, oh soul, in hard times - how you yearn for the homeland; at home or in a foreign country: how you yearn for the homeland! Let a deadly wind blow against you, let a deadly bullet meet you, you forget death and suffering and hurry towards the homeland.

Without any doubt the author of the poem uses the original image of a hive to denote Estonia and the pronoun it - referring to the bee symbolically extends to every Estonian and the entire nation, is one of the most powerful in the tradition of patriotic poetry. The reason, as explained by Jüri Talvet, is embedded in the existentiality of Liiv's poetry.

"Liiv transfers the anguish and the obsession with existence's limits to his people, Estonia," states Talvet and adds that for Liiv nationality means "a complete acceptance of responsibility: as long as the fault persists either in the conditions of the nation or in the nation itself, a responsible mind cannot flee or move apart, but has to assume the guilt." (Talvet 2007: 50-51)

Like with the other poems and phrases proceeding from them and living their own life, the major impact, which has also influenced the position of the phrase "Ta lendab mesipuu poole" in the internal communication of culture, is the fact that it is set to music. Composer Peep Sarapik (1949-1994) wrote the 
music and choirs have sung the song in Estonian Song Festivals since 1999. Its fixation as a sacral-rhetorical gesture is proved by the fact that the song, together with "Mu isamaa on minu arm" ("My Fatherland is my Love", music by Gustav Ernesaks, lyrics by Lydia Koidula), has become the second hymn of the song festivals and people sing it while standing up.

\section{"Kui Arno isaga koolimajja jõudis, olid tunnid juba alanud"}

One of the mot famous first sentences in world literature comes from Leo Tolstoi’s Anna Karenina: "All happy families are similar to each other, but every unhappy family is unhappy in its own way." In Estonian literature the most famous first sentence comes form Kevade (Spring) (1912/1913) - a novel by Oskar Luts (1877-1953) and reads as follows: "When Arno arrived at school together with his father, the lessons had already begun.” (Luts 1982: 7). The position of the writer Luts in Estonian literature has been discussed by the author in a paper published already earlier in Interlitteraria (Veidemann 2008: 356-363), and agrees with Aivar Kull, who has written in a monograph about Luts: "More than any other Estonian writer did Luts try to overcome "the grate of being different", which actually seems to be the secret of the everlasting impact of his creative work." (Kull 2007: 265)

Indeed, Luts presented characters conveying the features of certain archetypes, due to which they easily obtained the status of common Estonian language metaphors and idioms. For example, the nickname of the parish clerk Julk-Jüri, whose prototype was Alexander Georg Nieländer (in the novel: pastor Lender). Also characters presented by Luts act as metaphors in Estonian culture and society: Arno Tali, Toots, Kiir, Tõnisson, Imelik, Raja Teele, Lible, Laur. It is confirmed by the fact that the biggest Estonian weekly Maaleht has founded a non-profit organisation The Arno Tali Foundation, which awards the best teacher in Estonia the Prize of Teacher Laur. The mentioned foundation also awards scholarships to successful pupils called Arno and Teele Scholarships. The entire topos is metaphorised, proved by the fact that the place of action in the novel called Paunvere is used in the language equally with the place name Palamuse, which was the prototype of the place of action. The fair held in Palamuse every autumn is also called the Paunvere Fair.

\footnotetext{
4 'When Arno and his father arrived at school, the lessons had already begun'
} 
VEIDEMANN

But what makes the first sentence of the novel a rhetorical gesture in Estonian culture and society $?^{5}$ It is easy to perceive the similarity with old stories starting with the phrase "Once upon a time...". The story-teller takes the reader by hand and figuratively speaking opens the gates of the fairyland or the land of memories. Besides the specific chronological status, the initial sentence connects the reader with the special environment: school and lessons are described from the time aspect. Arno's story told does not start from the beginning but somewhere in the middle. In this way the reader experiences something that has started before him. The reader and his/her life is another row of words in the endless book of life. Arno's departure symbolises a departure of a much bigger importance in the reader's consciousness, as if God sends (Arno goes to school with his father!) the human being into the life struggle by saying: go and find your place. Besides this existentialistic reference also the national-mythological message of Kevade - the appraisal of the Estonian society as the home of the nation - is important. There are two home comings in the novel Kevade. The first one takes place when children go to school (the school as the second home, where pupils remain for the entire winter and Arno is going there), and the second one is in spring when the school ends and pupils go back to their parents. This one may be associated with the paradiselike original integrity. In the final scene of Kevade (in spring!) Teele asks Arno what is so important about home. And Arno responded: "Flowers...Meadows... Sunshine..." (Luts 1982: 301)

\section{“Tee tööd ja näe vaeva, siis tuleb armastus"6}

This is said by Andres of Vargamäe, a symbolic character in Estonian culture, to his son - Andres Junior at the end of the first volume of A. H. Tammsaare's (1878-1940) epic novel Truth and Justice (Tammsaare 1981: 492). The quoted phrase has become a rhetorical gesture probably due to the protestant work ethic, which characterised the basic value system of the Estonian peasant

5 I have observed in the public space of Estonia numerous speeches and pieces of writing, which apply the first sentence of Kevade as an idiom. For example, while the author was writing this paper, a polemic article was published against the structural reform initiated in Tartu University. Siret Schutting - the alumna of the university started her article (Schutting 2014) with the words, "When Arno arrived at school together with his father, the curriculum had been exchanged already". This shows what the first sentence of the beloved piece of writing would have looked like if Oskar Luts had been born a century later.

6 'Work hard and love will follow' 
society. Actually we are dealing with a paradox here, because irrespective of the manifestation of love in the saying, the son questions his father's words and this is how the circulating idiom is used in the collective communication of Estonians. Therefore, the context as a whole is rather ambivalent and lately even a shift of emphasis may be observed.

The episode itself describes how Andres Jr. is sent to serve in the army. Andres Jr. tells his father that the latter has to find a farm hand while he is away. Andres Sr. promises to manage without one. Andres Jr. hints hesitantly that he may not return home. Then father asks if he does not love Vargamäe at all. And Andres Jr. wonders why he should love Vargamäe when his father himself does not love it. He explains that his father is just sad to leave Vargamäe to strangers after he has put so much hard work into it. Why should children waste their lives at Vargamäe when it is much easier to live somewhere else? It would be meaningful only if there were love. Thereafter Andres Sr. tells his son that love requires hard work, but Andres Jr. denounces this and contradicts his father by saying:

"You have done that and my mother did it, that is why she died so young, but there was no love, and no love has come to Vargamäe up to the present day." (Tammsaare 1981: 492-493).

Besides the protestant work ethic in the words uttered by Andres Sr., we can also observe the understanding of life based on the Old Testament. It is the question of duty and atonement. A person may expect atonement to crown the sufferings and duties in his life. But when there is no atonement, a person is not freed from duties. The life of the human being is too short to see the results of one's commitment. At least it was like that in the Estonian peasant society at the end of the $19^{\text {th }}$ century, when Estonians became the actual masters of their land.

One of the metaphysical messages of Tammsaare's Truth and Justice constitutes the idea that love is the boundary value of infinity, which exists only in the movement towards it.

This applies to the love between a man and a woman, embodied by a platonic component. For example, Jaan Undusk considers Tammsaare's novel Ma armastasin sakslast (I loved a German) "a genuine and developed variant of platonic love" (Undusk 2013: 334). 
VEIDEMANN

\title{
Conclusion
}

The paper discusses only some examples of rhetorical gestures of literary origin circulating in Estonian culture. Their fixation has been possible due to education and their intensification in other genres of art. From the described aspect they may be observed as passwords of collective (resp national) identity, which uses signals to demonstrate affiliation to a certain cultural space.

However, the source of rhetorical gestures may be the speeches and articles of Estonian politicians and opinion leaders. ' Within the last decade the reservoir of rhetorical gestures has proved to be the social media (blogosphere). It has to be stressed that unlike traditional phraseologisms and idioms existing in the general language, rhetorical gestures develop according to the principle of post factum. Their use and impact depends on the situation. They metaphorise situations and attitudes. The rapid fragmentation of culture in the post-modern era and the variety of different languages and registers have narrowed down the effect of rhetorical gestures in space and time.

\author{
Rein Veidemann \\ rein.veidemann@tlu.ee \\ Tallinna Ülikool \\ Narva mnt 25 \\ 10120 Tallinn \\ EESTI
}

\section{References}

Corradi Fiumara, G. 1995. The Metaphoric Process. Connections between Language and Life. London: Routledge.

Craig, R. T. 1999. Communcation Theory as a Field. - Communication Theory, 9, May, 119-161.

EKSS 2009 = Eesti keele seletav sõnaraamat. 2009, 3, L-O. Tallinn: Eesti Keele Sihtasutus.

\footnotetext{
A good example was provided by Lennart Meri at the end of the 1990s who asked, "What is Estonian Nokia?" or in other words which kind of power would guarantee Estonia's economic success like it was in Finland with their state enterprise Nokia? Meri himself admitted that the repetitive use of this metaphoric question made it a part of Estonian folklore (Meri 2001: 333). Meri's question is actually a good example of how one or another rhetorical gesture may change in the course of time and conditions, obtaining an ironical or mocking meaning: today Finland has sold Nokia to Microsoft!
} 
About Rhetorical "Gestures" of Estonian Culture

Ennus, K. 2002. Iroonia ja keeletegevusõpetus. - Keel ja Kirjandus, 1, 4-16.

Haverkate, H. 1990. A Speech-Act Analysis of Irony. - Journal of Pragmatics, 14, 89100.

Henriku Liivimaa kroonika 1982. [R. Kleis, tr.] Tallinn: Eesti Raamat.

Jansen, E. 2004. Vaateid eesti rahvusluse sünniaegadesse. Tartu: Ilmamaa.

Kull, A. 2007. Oskar Luts.Tartu: Ilmamaa.

Laak, M. 2013. „Kalevipoeg“ kui tüvitekst. - Keel ja Kirjandus, 3, 192-209.

Liiv, J. 2007. Meel paremat ei kannata. The Mind Would Bear No Better. Ed. J. Talvet. Transl. J. Talvet, H. L. Hix. Tartu: Tartu Ülikooli Kirjastus.

Lotman, Y. 1990. Universe of Mind: A Semiotic Theory of Culture. London: I. B. Tauris $\&$ Co Ltd.

Lotman, M. 2001. Paradoksaalne semiosfäär (järelsõna). - J. Lotman, Kultuur ja plahvatus. Tallinn: Varrak, 215-226.

Luts, O. 1982. Kevade. Tallinn: Perioodika.

Meri, L. 2001. Riigimured. Tartu: Ilmamaa.

Oinas, F. 1994. Surematu Kalevipoeg. Tallinn: Keel ja Kirjandus.

Osterreich, P. L. 2002. Thesen zum homo rhetoricus und zur Neugestaltung der Philosophie im 21. Jahrhundert. - Rhetorica, XX, 3, 289-298.

Schutting, S 2014. Ühes vormiga muutub sisu. - Eesti Päevaleht, 19.06.

Talvet, J. 2007. Juhan Liiv and His Existential Poetry. - J. Liiv, Meel paremat ei kannata. The Mind Would Bear No Better. Tartu: Tartu Ülikooli Kirjastus, 29-52.

Tammsaare, A. H. 1981. Tõde ja õigus I. Tallinn: Eesti Raamat.

Undusk, J. 2013. Armastus ja sotsioloogia. Sissevaade Tammsaare omailma. M. Hinrikus, J. Undusk, eds., Armastus ja sotsioloogia. A. H. Tammsaare romaan „Ma armastasin sakslast”. Tallinn: Underi ja Tuglase Kirjanduskeskus, 242-342.

Valk, H. 2004. Personal interview.

Veidemann, R. 2008. About the Ecumenical Structure of Estonian (literary) Culture: the Case of Kevade ('Spring') by Oskar Luts. - Interlitteraria, 13/2, 356-363.

Veidemann, R. 2011. Symbols as Means of Creating Cultural Communication and Identity. The Estonian Case. - Interlitteraria, 16/2, 419-440. 